\title{
PERMINTAAN DAGING SAPI DI PROVINSI RIAU
}

\author{
Demand for Beef in Riau Province
}

\author{
Fadhlan Syihabuddin, Elinur, Sisca Vaulina \\ Program Studi Agribisnis Fakultas Pertanian Universitas Islam Riau \\ Email : f.syihabuddin@yahoo.com \\ [Diterima: Desember 2018; Disetujui: April 2019]
}

\begin{abstract}
The husbandry sub-sector is a source of supporting energy for human needs, especially beef. Beef is a food commodity that has had an impact on improving public nutrition, especially animal protein. This study aims to analyze the development of beef demand and variables that influence it in Riau, the factors that influence beef demand in Riau Province, and the price elasticity, income elasticity, and cross elasticity of factors affecting meat demand beef in Riau Province. This research used the literature study. The data used in this research was data time series from 1999 to 2015. Data were analyzed using descriptive statistics, multiple linear regression, and elasticity. The results showed that the overall average development of beef demand, beef prices, chicken meat prices, rice prices, population income, and the population increased during the period. The factors that significantly influence the demand for beef were the price of beef and the price of rice. Meanwhile, the price of chicken meat, the income of the population, and the population had no significant to the demand for beef. The results of the elasticity calculation of demand showed that beef prices, rice prices, and population income were responsive to beef demand. This indicates that changes in beef prices, rice prices, and population income had a major impact on changes in demand for beef.
\end{abstract}

Keywords: Beef, Demand, and Elasticity

\begin{abstract}
ABSTRAK
Subsektor peternakan merupakan penopang sumber energi untuk kebutuhan manusia terutama daging sapi. Daging sapi merupakan salah satu komoditas pangan yang selama ini memberikan pengaruh terhadap perbaikan gizi masyarakat, khususnya protein hewani. Penelitian ini bertujuan untuk menganalisis (1) perkembangan permintaan daging sapi dan variabel yang mempengaruhinya di Provinsi Riau (2) faktor-faktor yang mempengaruhi permintaan daging sapi di Provinsi Riau (3) elastisitas harga, elastisitas pendapatan dan elastisitas silang terhadap faktor yang mempengaruhi permintaan daging sapi di Provinsi Riau. Penelitian ini menggunakan metode kepustakaan. Jenis data yang digunakan dalam penelitian ini adalah data time series dari tahun 1999-2015. Data dianalisis menggunakan statistik deskriptif, regresi linier berganda dan analisis elastisitas. Hasil penelitian menggambarkan bahwa secara keseluruhan rata-rata perkembangan permintaan daging sapi, harga daging sapi, harga daging ayam, harga beras, pendapatan penduduk dan jumlah penduduk mengalami peningkatan. Faktor-faktor yang mempengaruhi permintaan daging sapi secara signifikan adalah harga daging sapi dan harga beras. Sedangkan harga daging ayam, pendapatan penduduk dan jumlah penduduk tidak signifikan terhadap permintaan daging sapi. Hasil perhitungan elastisitas permintaan bahwa harga daging sapi, harga beras dan pendapatan penduduk responsif terhadap permintaan daging sapi. Hal ini mengindikasikan perubahan harga daging sapi, harga beras dan pendapatan penduduk berdampak besar terhadap perubahan permintaan daging sapi.
\end{abstract}

Kata kunci: Daging Sapi, Permintaan dan Elastisitas

\section{PENDAHULUAN}

Daging sapi merupakan salah satu komoditi pertanian yang diperlukan untuk memenuhi kebutuhan protein hewani yang bermutu tinggi. Oleh karena itu daging sapi dibutuhkan oleh tubuh manusia sehingga permintaan daging sapi meningkat. Seiring dengan perkembangan penduduk permintaan daging sapi di Provinsi Riau meningkat dari tahun ke tahun, sehingga pola konsumsi penduduk juga berubah yang semula lebih banyak mengkonsumsi karbohidrat mengurangi 
dengan menambah mengkonsumsi daging sapi, telur dan susu.

Menurut BPS (2016) bahwa konsumsi daging secara umum penduduk di Provinsi Riau mengalami peningkatan. Pada tahun 2011 konsumsi daging sebanyak $3,86 \mathrm{~kg} / \mathrm{kapita} / \mathrm{hari}$ meningkat menjadi $4,76 \mathrm{~kg} / \mathrm{kapita} / \mathrm{hari}$ pada tahun 2015. Meningkatnya konsumsi daging sapi di Provinsi Riau akan meningkatan pengeluaran rumahtangga di Provinsi Riau. Pada tahun 2011 pengeluaran masyarakat terhadap daging secara umum sebesar Rp. 15.747 kapita/bulan meningkat menjadi Rp. $20.371 \mathrm{kapita} / \mathrm{bulan}$.

\begin{tabular}{|c|c|c|}
\hline akin & $\begin{array}{l}\text { tingginya } \\
\text { terhadap }\end{array}$ & $\begin{array}{l}\text { kur } \\
\text { das }\end{array}$ \\
\hline
\end{tabular}
menyebabkan peningkatan terhadap permintaan daging sapi. Selain itu peningkatan permintaan daging sapi juga disebabkan oleh peningkatan jumlah penduduk Provinsi Riau. Pada tahun 2013 jumlah penduduk sebanyak 6.033.268 jiwa meningkat menjadi 6.344 .402 jiwa pada tahun 2015. Selain peningkatan jumlah penduduk permintaan daging sapi juga disebabkan oleh peningkatan pendapatan penduduk. Pendapatan penduduk ditunjukkan oleh PDRB total regional penduduk Provinsi Riau. Pendapatan penduduk tahun 2012 sebesar Rp 299.460.259,76 meningkat menjadi Rp. Rp 358.490.270 pada tahun 2015 .

Permintaan suatu barang ditentukan oleh harga barang sendiri, harga barang lain yang berhubungan dengan barang tersebut, pendapatan penduduk, jumlah penduduk dan selera (Sugiarto dkk, 2005). Dengan demikian permintaan daging sapi menerangkan sifat dari permintaan pembeli terhadap komoditas daging sapi, sehingga permintaannya ditentukan oleh harga daging sapi, harga daging ayam, harga beras, pendapatan penduduk dan jumlah penduduk. Sedangkan selera untuk mengkonsumsi daging sapi di asusmsikan sama sehingga selera dianggap konstan. Dengan demikian penulis tertarik untuk melakukan tentang Permintaan Daging Sapi di Provinsi Riau.

Adapun tujuan dalam penelitian ini adalah untuk menganalisis perkembangan permintaan daging sapi dan varibel yang mempengaruhinya, faktor yang mempengaruhi permintaan daging sapi di Provinsi Riau, elastisitas harga dan silang terhadap permintaan daging sapi di Provinsi Riau.

\section{METODOLOGI PENELITIAN}

Metode penelitian ini adalah metode kepustakaan, yaitu menelusuri dan menelaah literatur yang ada di perpustakaan. Data yang digunakan dalam penelitian ini adalah sekunder, data time series (data deret waktu) dari tahun 1995-2015 atau kurun waktu 17 tahun. Data yang dikumpulkan meliputi harga daging sapi, harga daging ayam, harga beras, pendapatan penduduk dan jumlah penduduk.

Metode analisis yang digunakan dalam penelitian ini adalah metode statistik deskriptif untuk menjawab tujuan pertama dan metode statistik kuantitatif. Rumus menghitung pertumbuhan ekonomi adalah sebagai berikut:

Pertumbuhan $=\frac{\mathrm{Q}_{1}-\mathrm{Q}_{0}}{\mathrm{Q}_{0}} \times 100 \%$

Dimana:

$$
\begin{aligned}
& \mathrm{Q}_{1}=\text { Periode Tahun } \mathrm{t} \\
& \mathrm{Q}_{0}=\text { Periode Tahun }-\mathrm{t}
\end{aligned}
$$

Untuk menganalisis faktor-faktor yang mempengaruhi permintaan daging. Metode statistik kuantitatif mengggunakan analisis regresi berganda. Model permintaan daging di Provinsi Riau dapat dirumuskan:

$\mathrm{Y}=\mathrm{a}+\mathrm{b}_{1} \mathrm{X}_{1}+\mathrm{b}_{2} \mathrm{X}_{2}+\mathrm{b}_{3} \mathrm{X}_{3}+\mathrm{b}_{4} \mathrm{X}_{4}+\mathrm{b}_{5} \mathrm{X}_{5}+\mathrm{e}$

Dimana :

$$
\begin{array}{ll}
\mathrm{Y} & =\text { Permintaan Daging Sapi }(\mathrm{Kg} / \mathrm{Th}) \\
\mathrm{X}_{1} & =\text { Harga Daging Sapi }(\mathrm{Rp} / \mathrm{Kg} / \mathrm{Th}) \\
\mathrm{X}_{2} & =\text { Harga Daging Ayam }(\mathrm{Rp} / \mathrm{Kg} / \mathrm{Th}) \\
\mathrm{X}_{3} & =\text { Harga Beras }(\mathrm{Rp} / \mathrm{Kg} / \mathrm{Th}) \\
\mathrm{X}_{4} & =\text { Pendapatan Penduduk }(\mathrm{Rp} / \mathrm{Th}) \\
\mathrm{X}_{5} & =\text { Jumlah Penduduk (Jiwa/Th) } \\
\mathrm{b}_{1}-\mathrm{b}_{5} & =\text { Parameter Dugaan } \\
\mathrm{e} & =\text { Error }
\end{array}
$$

Parameter dugaan yang diharapkan: $\beta_{0}, \beta_{2}, \beta_{3}, \beta_{4}, \beta_{5}>0$ dan $\beta_{1}<0$

Elastisitas digunakan untuk menguji tingkat kepekaan jumlah permintaan terhadap perubahan yang terjadi pada variabel-variabel yang diteliti digunakan elastisitas harga, elastisitas pendapatan dan elastisitas silang.

Adapun rumus elastisitas harga yaitu :

$\eta p=\frac{\partial \mathrm{Q}_{\mathrm{ds}}}{\partial \mathrm{P}_{\mathrm{ds}}} \times \frac{\mathrm{P}_{\mathrm{ds}}}{\mathrm{Q}_{\mathrm{ds}}}=\beta_{1} \times \frac{\overline{\mathrm{P}}_{\mathrm{ds}}}{\overline{\mathrm{Q}}_{\mathrm{ds}}} \ldots$

Menurut Sugiarto dkk (2005) kriteria elastisitas harga sebagai berikut:

a. Tidak elastis (bernilai antara 0 dan 1), Jika perubahan harga sebesar 1 persen menyebabkan perubahan jumlah 
komoditas yang diminta kurang dari 1 persen.

b. Elastis (nilai $\eta p>1$ ), Jika perubahan harga sebesar 1 persen menyebabkan perubahan jumlah yang diminta lebih dari 1 persen.

Rumus elastisitas pendapatan yaitu:

$\eta \mathrm{I}=\frac{\partial \mathrm{Q}_{\mathrm{ds}}}{\partial \mathrm{I}} \times \frac{\mathrm{I}}{\mathrm{Q}_{\mathrm{ds}}}=\beta_{4} \times \frac{\overline{\mathrm{I}}}{\overline{\mathrm{Q}}_{\mathrm{ds}}}$.

Menurut Sugiarto dkk (2005) adapun acuan umum pengelompokan kategori suatu komoditas adalah sebagai berikut:

a. $\eta \mathrm{I}$ : - Komoditas Inferior (komoditas bermutu rendah)

b. $\eta \mathrm{I}:+$ Komoditas Normal

c. $\eta \mathrm{I}:>1$ Komoditas mewah

d. $\eta \mathrm{I}:<1$ komoditas kebutuhan pokok
Rumus elastisitas silang yaitu :

$\eta \mathrm{c}=\frac{\partial \mathrm{Q}_{\mathrm{ds}}}{\partial \mathrm{P}_{\mathrm{b}}} \times \frac{\mathrm{P}_{\mathrm{b}}}{\mathrm{Q}_{\mathrm{ds}}}=\beta_{3} \times \frac{\overline{\mathrm{P}}_{\mathrm{b}}}{\overline{\mathrm{Q}}_{\mathrm{ds}}}$

Menurut Sugiarto dkk (2005) Untuk

komoditas pelengkap (complement) elastisitas silangnya bernilai negatif. Sedangkan untuk komoditas pengganti (substitusi), elastisitas silangnya adalah positif.

\section{HASIL DAN PEMBAHASAN}

\section{Pertumbuhan Daging Sapi dan Varibel yang Mempengaruhinya}

Permintaan daging sapi di Provinsi Riau pertahunnya cenderung mengalami peningkatan. Hal ini dapat dilihat pada Tabel 1

Tabel 1. Permintaan Daging Sapi di Propinsi Riau, Tahun 1999-2015

\begin{tabular}{ccc}
\hline Tahun & Permintaan Daging Sapi $(\mathrm{Kg})$ & Pertumbuhan $(\%)$ \\
\hline 1999 & $463.407,56$ & 0 \\
2000 & $573.670,65$ & 0,23 \\
2001 & $614.571,20$ & 0,07 \\
2002 & $825.059,00$ & 0,34 \\
2003 & $662.014,80$ & $-0,19$ \\
2004 & $673.708,95$ & 0,01 \\
2005 & $692.239,50$ & 0,02 \\
2006 & $905.198,95$ & 0,30 \\
2007 & $1.115 .609,44$ & 0,23 \\
2008 & $1.191 .937,51$ & 0,06 \\
2009 & $1.234 .032,34$ & 0,03 \\
2010 & $1.329 .208,08$ & 0,07 \\
2011 & $1.488 .822,66$ & 0,12 \\
2012 & $2.234 .061,42$ & 0,50 \\
2013 & $2.171 .976,48$ & $-0,02$ \\
2014 & $2.537 .261,22$ & 0,16 \\
2015 & $2.981 .868,94$ & 0,17 \\
\hline Rata-rata & $1.276 .155,80$ & 0,13
\end{tabular}

Sumber: Badan Ketahanan Pangan Riau, 2000-2016

Berdasarkan Tabel 1 dapat dilihat pada pertumbuhan rata-rata permintaan daging sapi yaitu 0,13 persen atau sebanyak $1.276 .155,80$ kg. Pada tahun 2012 terjadi peningkatan pertumbuhan permintaan daging sapi yang tertinggi yaitu 0,50 persen atau sebanyak 2.234.061,42 kg. Sedangkan pertumbuhan permintaan daging sapi yang mengalami penurunan terendah terjadi pada tahun $2002 \mathrm{ke}$ 2003 dengan persentase yaitu $-0,19$ persen atau sebanyak $662.014,80 \mathrm{~kg}$.

Harga daging sapi di Provinsi Riau pertahunnya cenderung mengalami peningkatan. Hal ini dapat dilihat pada Tabel 2.
Berdasarkan Tabel 2 dapat dilihat pada pertumbuhan rata-rata harga daging sapi yaitu 0,11 persen atau sebesar Rp. 57.057,65/kg. Peningkatan dengan pertumbuhan tertinggi harga daging sapi terjadi pada tahun 2010 dengan persentase 0,61 persen atau sebesar Rp. $62.993,00 / \mathrm{kg}$. Sedangkan pertumbuhan harga daging sapi yang mengalami penurunan terendah terjadi pada tahun 2008 ke 2009 dengan persentase yaitu $-0,39$ persen atau sebesar Rp. 39.022,00/kg. 
Tabel 2. Harga Daging Sapi di Propinsi Riau, Tahun 1999-2015

\begin{tabular}{ccc}
\hline Tahun & Harga Daging Sapi $(\mathrm{Rp} / \mathrm{Kg})$ & Pertumbuhan $(\%)$ \\
\hline 1999 & $24.734,67$ & 0 \\
2000 & $31.317,89$ & 0,27 \\
2001 & $34.854,32$ & 0,11 \\
2002 & $36.195,83$ & 0,04 \\
2003 & $36.758,33$ & 0,02 \\
2004 & $39.936,00$ & 0,09 \\
2005 & $46.005,00$ & 0,15 \\
2006 & $54.244,00$ & 0,18 \\
2007 & $59.184,00$ & 0,09 \\
2008 & $64.046,00$ & 0,08 \\
2009 & $39.022,00$ & $-0,39$ \\
2010 & $62.993,00$ & 0,61 \\
2011 & $67.077,00$ & 0,06 \\
2012 & $76.692,00$ & 0,14 \\
2013 & $92.843,00$ & 0,21 \\
2014 & $99.751,00$ & 0,07 \\
2015 & $104.326,00$ & 0,05 \\
\hline Rata-rata & $57.057,65$ & 0,11 \\
\hline
\end{tabular}

Sumber: Badan Ketahanan Pangan Riau, 2000-2016

Tabel 3. Harga Daging Ayam di Propinsi Riau, Tahun 1999-2015

\begin{tabular}{ccc}
\hline Tahun & Harga Daging Ayam $(\mathrm{Rp} / \mathrm{Kg})$ & Pertumbuhan $(\%)$ \\
\hline 1999 & $13.814,77$ & 0 \\
2000 & $15.607,65$ & 0,13 \\
2001 & $17.784,68$ & 0,14 \\
2002 & $19.447,82$ & 0,09 \\
2003 & $19.782,05$ & 0,02 \\
2004 & $19.610,66$ & $-0,01$ \\
2005 & $21.961,08$ & 0,12 \\
2006 & $25.182,45$ & 0,15 \\
2007 & $25.255,29$ & 0,00 \\
2008 & $25.692,00$ & 0,02 \\
2009 & $27.655,00$ & 0,08 \\
2010 & $20.013,00$ & $-0,28$ \\
2011 & $23.969,00$ & 0,20 \\
2012 & $24.533,00$ & 0,02 \\
2013 & $24.532,00$ & 0,00 \\
2014 & $24.664,00$ & 0,01 \\
2015 & $27.104,00$ & 0,10 \\
\hline Rata-rata & $22.153,44$ & 0,05 \\
\hline
\end{tabular}

Sumber: BPS Indonesia, 2000-2016

Harga daging ayam di Provinsi Riau pertahunnya cenderung mengalami peningkatan. Hal ini dapat dilihat pada Tabel 3.

Berdasarkan Tabel 3 dapat dilihat pada pertumbuhan rata-rata harga daging ayam yaitu 0,05 persen atau sebesar Rp. 22.153,44/kg. Peningkatan dengan pertumbuhan tertinggi terjadi tahun 2011 dengan persentase 0,20 persen atau sebesar Rp. 23.969,00/kg. Sedangkan pertumbuhan yang mengalami penurunan terendah terjadi tahun 2009 ke 2010 dengan persentase $-0,28$ persen atau sebesar Rp. $20.013,00 / \mathrm{kg}$.
Harga beras di Provinsi Riau pertahunnya cenderung mengalami peningkatan. Hal ini dapat dilihat pada Tabel 4.

Berdasarkan Tabel 4 dapat dilihat pada pertumbuhan rata-rata harga beras yaitu 0,11 persen atau sebesar Rp. 6.208,37/kg. Pertumbuhan harga beras yang mengalami penurunan terendah terjadi pada tahun $2002 \mathrm{ke}$ 2003 dengan persentase $-0,08$ persen dengan harga beras sebesar Rp. 2.934,97/kg. Sedangkan pertumbuhan yang mengalami peningkatan tertinggi pada harga beras terjadi 
pada tahun 2011 dengan persentase 0,30 persen atau sebesar Rp. 9.967,00/kg.

Pendapatan penduduk di Provinsi Riau pertahunnya cenderung mengalami peningakatan. Hal ini dapat dilihat pada Tabel 5 .

Tabel 4. Harga Beras di Propinsi Riau, Tahun 1999-2015

\begin{tabular}{ccc}
\hline Tahun & Harga Beras $(\mathrm{Rp} / \mathrm{Kg})$ & Pertumbuhan $(\%)$ \\
\hline 1999 & $2.356,80$ & 0 \\
2000 & $2.939,59$ & 0,25 \\
2001 & $2.756,41$ & $-0,06$ \\
2002 & $3.185,98$ & 0,16 \\
2003 & $2.934,97$ & $-0,08$ \\
2004 & $3.229,42$ & 0,10 \\
2005 & $4.117,14$ & 0,27 \\
2006 & $4.903,00$ & 0,19 \\
2007 & $5.992,00$ & 0,22 \\
2008 & $6.619,00$ & 0,10 \\
2009 & $6.541,00$ & $-0,01$ \\
2010 & $7.686,00$ & 0,18 \\
2011 & $9.967,00$ & 0,30 \\
2012 & $10.038,00$ & 0,01 \\
2013 & $10.328,00$ & 0,03 \\
2014 & $10.552,00$ & 0,02 \\
2015 & $11.396,00$ & 0,08 \\
\hline Rata-rata & $6.208,37$ & 0,11 \\
\hline
\end{tabular}

Sumber: BPS Riau, 2000-2016

Tabel 5. Pendapatan Total Regional Propinsi Riau, Tahun 1999-2015

\begin{tabular}{|c|c|c|}
\hline Tahun & Pendapatan Total Regional (Rp) & Pertumbuhan $(\%)$ \\
\hline 1999 & $8.753 .869,76$ & 0 \\
\hline 2000 & $9.649 .875,59$ & 0,10 \\
\hline 2001 & $10.146 .823,25$ & 0,05 \\
\hline 2002 & $26.188 .113,44$ & 1,58 \\
\hline 2003 & 28.326.774,11 & 0,08 \\
\hline 2004 & $30.879 .767,77$ & 0,09 \\
\hline 2005 & $33.516 .541,66$ & 0,09 \\
\hline 2006 & $36.417 .633,12$ & 0,09 \\
\hline 2007 & $39.420 .760,09$ & 0,08 \\
\hline 2008 & $42.596 .930,48$ & 0,08 \\
\hline 2009 & $45.391 .943,91$ & 0,07 \\
\hline 2010 & $279.975 .284,49$ & 5,17 \\
\hline 2011 & $292.123 .408,95$ & 0,04 \\
\hline 2012 & $299.460 .259,76$ & 0,03 \\
\hline 2013 & $301.582 .584,28$ & 0,01 \\
\hline 2014 & $305.044 .781,67$ & 0,01 \\
\hline 2015 & $358.490 .270,09$ & 0,18 \\
\hline Rata-rata & $126.350 .918,97$ & 0,48 \\
\hline \multicolumn{2}{|c|}{$\begin{array}{l}\text { Berdasarkan Tabel } 5 \text { dapat dilihat pada } \\
\text { pertumbuhan rata-rata pendapatan total } \\
\text { regional yaitu } 0,48 \text { persen atau sebesar Rp. } \\
126.350 .918,97 \text {. Pertumbuhan pendapatan total } \\
\text { regional yang mengalami penurunan terendah } \\
\text { terjadi pada tahun } 2012 \text { ke } 2013 \text { dengan } \\
\text { persentase } 0,01 \text { persen dengan pendapatan total }\end{array}$} & $\begin{array}{l}\text { pada tahun } 2010 \text { dengan persentase } 5,17 \\
\text { persen atau sebesar Rp. } 279.975 .284,49 . \\
\text { Jumlah penduduk di Provinsi Riau } \\
\text { pertahunnya cenderung } \\
\text { peningkatan. Hal ini dapat dilihat pada Tabel } \\
6 . \\
\text { Berdasarkan Tabel } 6 \text { pertumbuhan rata- } \\
\text { rata jumlah penduduk yaitu } 0,04 \text { persen atau } \\
\text { sebanyak 5.003.464,00 jiwa. Pertumbuhan } \\
\text { jumlah penduduk yang mengalami penurunan }\end{array}$ \\
\hline
\end{tabular}


terendah terjadi pada tahun 2000 ke 2001 dengan persentase 0,00 persen dengan jumlah penduduk sebanyak 3.841.070,00 jiwa. Sedangkan peningkatan pertumbuhan tertinggi terjadi pada tahun 2002 dengan persentase 0,07 persen atau sebanyak 4.125.295,00 jiwa.

Tabel 6. Jumlah Penduduk di Propinsi Riau, Tahun 1999-2015

\begin{tabular}{ccc}
\hline Tahun & Jumlah Penduduk (Jiwa) & Pertumbuhan $(\%)$ \\
\hline 1999 & $3.655 .616,00$ & 0 \\
2000 & $3.824 .471,00$ & 0,04 \\
2001 & $3.841 .070,00$ & 0,00 \\
2002 & $4.125 .295,00$ & 0,07 \\
2003 & $4.413 .432,00$ & 0,07 \\
2004 & $4.491 .393,00$ & 0,01 \\
2005 & $4.614 .930,00$ & 0,02 \\
2006 & $4.764 .205,00$ & 0,03 \\
2007 & $5.070 .952,00$ & 0,06 \\
2008 & $5.182 .337,00$ & 0,02 \\
2009 & $5.365 .358,00$ & 0,03 \\
2010 & $5.538 .367,00$ & 0,03 \\
2011 & $5.726 .241,00$ & 0,03 \\
2012 & $5.879 .109,00$ & 0,02 \\
2013 & $6.033 .268,00$ & 0,02 \\
2014 & $6.188 .442,00$ & 0,02 \\
2015 & $6.344 .402,00$ & 0,02 \\
\hline Rata-rata & $5.003 .464,00$ & 0,04 \\
\hline
\end{tabular}

Sumber: BPS Riau, 2000-2016

Faktor-Faktor yang Mempengaruhi Permintaan Daging Sapi di Provinsi Riau Permintaan daging merupakan jumlah daging yang dibeli atau yang diminta konsumen pada harga dan waktu tertentu.

Tabel 7. Faktor Dominan yang Mempengaruhi Permintaan Daging Sapi di Provinsi Riau Tahun 2017

\begin{tabular}{|c|c|c|c|c|c|}
\hline Variabel & $\begin{array}{c}\text { Parameter } \\
\text { Estimasi }\end{array}$ & T hit & Prob T & VIF & Elastisitas \\
\hline Konstanta & 1.93278 & 2.48 & 0.0323 & 0 & - \\
\hline Harga Daging Sapi & -0.00005280 & -1.85 & 0.0939 & 1.07719 & -8.83 \\
\hline Harga Daging Ayam & -0.00004856 & -0.64 & 0.5345 & 3.38329 & - \\
\hline Harga Beras & 0.00029536 & 8.42 & $<.0001$ & 1.09801 & 1.43 \\
\hline Pendapatan Masyarakat & -0.00134 & -0.90 & 0.3882 & 3.31912 & -4.77 \\
\hline Jumlah Penduduk & $1.078518 \mathrm{E}-7$ & 0.15 & 0.8816 & 1.10944 & - \\
\hline $\mathrm{R}$-Square $\left(\mathrm{R}^{2}\right)$ & & & & & 0.8939 \\
\hline F hitung & & & & & 16.85 \\
\hline F sig & & & & & 0.0001 \\
\hline Durbin-Watson & & & & & 1.142 \\
\hline
\end{tabular}

Keterangan : nyata pada taraf kepercayaan $\alpha=10$ persen

Berdasarkan Tabel 7 dapat dilihat nilai parameter estimasi harga daging sapi sebesar 0.00005280. Artinya, apabila harga daging sapi meningkat Rp. $1.000,00$ maka permintaan daging sapi akan menurun sebanyak $0.00005280 \mathrm{~kg}$. Secara parsial variabel harga daging sapi berpegaruh signifikan terhadap permintaan daging sapi itu sendiri dengan nilai $\mathrm{t}$ sig sebesar 0.093 yang berarti lebih kecil dari 10 persen. Hasil penelitian ini senada dengan hasil penelitian Ilham (2001), permintaan
Permintaan daging ditentukan oleh keinginan konsumen. Faktor yang menentukan permintaan daging di sajikan pada Tabel 7. daging sapi dipengaruhi oleh harga daging sapi, artinya bahwa keputusan mengkonsumsi daging sapi tidak hanya ditentukan oleh pendapatan tetapi tingkat pendidikan dan aksebilitas masyarakat terhadap fasilitas sosial ekonomi. Fatmawati dkk (2016), bahwa permintaan daging sapi dipengaruhi oleh konsumsi daging sapi dan pendapatan masyarakat.

Harga daging ayam nilai parameter estimasinya sebesar -0.00004856 . Artinya, 
apabila harga daging ayam meningkat $\mathrm{Rp}$. 1.000,00 maka permintaan daging sapi akan menurun sebanyak $0.00004856 \mathrm{~kg}$. Secara parsial variabel harga daging ayam tidak berpegaruh signifikan terhadap permintaan daging sapi dengan nilai $t$ sig sebesar 0.534 yang berarti lebih besar dari 10 persen.

Harga beras nilai parameter estimasinya sebesar 0.00029536. Artinya, apabila harga beras meningkat Rp. $1.000,00$ maka permintaan daging sapi juga akan meningkat sebanyak $0.00029536 \mathrm{~kg}$. Secara parsial variabel harga beras berpegaruh positif dan signifikan terhadap permintaan daging sapi dengan nilai t sig sebesar $<, 0001$ yang berarti lebih kecil dari 10 persen.

Pendapatan penduduk nilai parameter estimasinya sebesar -0.00134 . Artinya apabila pendapatan masyarakat meningkat $\mathrm{Rp}$. 1.000.000,00 maka proporsi pendapatan terhadap permintaan daging sapi akan menurun sebanyak $0.00134 \mathrm{~kg}$. Secara parsial variabel pendapatan penduduk tidak berpengaruh signifikan terhadap permintaan daging sapi dengan nilai $\mathrm{t}$ sig sebesar 0,388 yang berarti lebih besar dari 10 persen. Hal ini berbeda dengan hasil penelitian Zulkarnain (2016); Liu et al (2015); Munarka dkk (2015); Ugwumba et al (2013), yang menyatakan bahwa pendapatan mempengaruhi konsumsi daging sapi. Obara et al (2010) menyebutkan dalam Japan's beef market, konsumsi daging sapi akan meningkat signifikan jika tingkat pendapatan meningkat atau ketika harga daging sapi turun.

Jumlah penduduk nilai parameter estimasinya sebesar 1.078518E-7. Artinya, apabila jumlah penduduk meningkat 1 persen, maka permintaan daging sapi akan meningkat sebanyak 1.078518E-7 kg. Secara parsial variabel jumlah penduduk tidak berpengaruh signifikan terhadap permintaan daging sapi dengan nilai $t$ sig sebesar 0.881 yang berarti lebih besar dari 10 persen.

Nilai koefisien determinasi $\left(\mathrm{R}^{2}\right)$ sebesar 0.8939. Hal ini berarti variasi variabel independen (harga daging sapi, harga daging ayam, harga beras, pendapatan penduduk dan jumlah penduduk) mampu menjelaskan variabel dependen permintaan daging sapi sebesar 89,39 persen dan sisanya 10,61 persen dijelaskan oleh variabel lain yang tidak dimasukkan kedalam model. Elastisitas Permintaan
Elastisitas harga daging sapi terhadap permintaan daging sapi yaitu $-8,83$. Hal ini berarti apabila harga daging sapi meningkat sebesar 1 persen, maka permintaan daging sapi akan menurun sebanyak $8,83 \mathrm{~kg}$. Elastisitas harga daging sapi bersifat elastis. Artinya bahwa persentase perubahan harga daging sapi berdampak lebih besar terhadap perubahan jumlah permintaan daging sapi. Handayani dkk (2016), dilihat dari analisis elastisitas menunjukkan bahwa permintaan daging sapi tidak responsif terhadap harga daging sapi domestik baik dalam jangka pendek maupun jangka panjang dengan nilai masing-masing 0,014 dan $-0,020$.

Elastisitas pendapatan terhadap permintaan daging sapi yaitu $-4,77$. Hal ini berarti apabila terjadi kenaikan pendapatan sebesar 1 persen, maka akan mengakibatkan berkurangnya jumlah permintaan daging sapi sebanyak $4.77 \mathrm{~kg}$. Pendapatan penduduk bersifat elastis. Artinya bahwa persentase perubahan pendapatan berdampak lebih besar dari pada perubahan jumlah permintaan daging sapi. Hasil penelitian Kadju dkk (2014) memberikan informasi mengenai elastisitas pendapatan sebesar 0,952 artinya bahwa elastisitas pendapatan terhadap permintaan daging sapi bersifat hampir elastis.

Elastisitas silang harga beras terhadap permintaan daging sapi yaitu sebesar 1.43. Hal ini berarti apabila harga beras meningkat sebesar 1 persen, maka permintaan daging sapi akan meningkat sebanyak $1.43 \mathrm{~kg}$. Harga beras bersifat elastis. Artinya bahwa persentase perubahan harga beras lebih besar dari pada perubahan jumlah permintaan daging sapi.

Perkembangan permintaan daging sapi, harga daging sapi, harga daging ayam, harga beras, pendapatan penduduk dan jumlah penduduk mengalami peningkatan. Secara parsial variabel yang berpengaruh signifikan terhadap permintaan daging sapi di Provinsi Riau adalah harga daging sapi dan harga beras. Adapun variabel yang tidak berpegaruh terhadap permintaan daging sapi adalah harga daging ayam, pendapatan penduduk dan jumlah penduduk. Elastisitas harga daging sapi, elastisitas pendapatan dan elastisitas silang harga beras tergolong elastis. Hal ini berarti perubahan harga daging sapi, perubahan pendapatan dan perubahan harga beras berdampak lebih besar dari pada perubahan jumlah permintaan daging sapi. 


\section{KESIMPULAN}

Berdasarkan hasil penelitian yang telah dilaksanakan dapat ditarik kesimpulan bahwa:

1. Permintaan daging sapi di Provinsi Riau pertahunnya cenderung mengalami peningkatan, begitupula dengan variabel yang mempengaruhinya (harga daging sapi, harga daging ayam; harga beras, pendapatan masyarakat dan jumlah penduduk).

2. Nilai koefisien determinasi $\left(\mathrm{R}^{2}\right)$ sebesar 0.8939 , artinya bahwa variasi variabel independen (harga daging sapi, harga daging ayam, harga beras, pendapatan penduduk dan jumlah penduduk) mampu menjelaskan variabel dependen permintaan daging sapi sebesar 89,39 persen.

3. Elastisitas harga daging sapi terhadap permintaan daging sapi yaitu $-8,83$. Elastisitas pendapatan terhadap permintaan daging sapi yaitu $-4,77$. Elastisitas silang harga beras terhadap permintaan daging sapi yaitu sebesar 1.43.

\section{DAFTAR PUSTAKA}

Badan Pusat Statistik. 2016. Riau Dalam Angka. Badan Pusat Statistik Provinsi Riau, Pekanbaru.

Badan Pusat Statistik. 2011. Riau Dalam Angka. Badan Pusat Statistik Provinsi Riau, Pekanbaru.

Badan Pusat Statistik. 2006. Riau Dalam Angka. Badan Pusat Statistik Provinsi Riau, Pekanbaru.

Badan Pusat Statistik. 2002. Statistik Harga Konsumen Pedesaan di Indonesia. Badan Pusat Statistik Indonesia, Jakarta.

Badan Ketahanan Pangan Provinsi Riau. 2015. Statistik Pangan Tahun 2014. Badan Ketahanan Pangan Provinsi Riau, Pekanbaru.

Fatmawati, Rostin dan Jamal Nasir Baso. 2016. Faktor-Faktor yang Mempengaruhi Permintaan Daging Sapi di Indonesia. Jurnal Ekonomi (JE), 1 (1): 128-134

Handayani, S., Anna Fariyanti, Rita Nurmalina. 2016. Swasembada Daging Sapi Analisis Simulasi Ramalan Swasembada Daging Sapi di Indonesia. Sosiohumaniora, 18 (1): 61-70

Ilham, N. 2001. Analisis Penawaran dan Permintaan Daging Sapi di Indonesia. Prosiding Seminar Nasional Teknologi
Peternakan dan Veteriner, 385-403

Kadju, F. Y. D., Fabian Heri Lawalu., Maria Yasinta Luruk. 2014. Analisis Permintaan Daging Sapi di Kota Kupang. Jurnal Nukleus Peternakan, 1 (2):123-129.

Heriyanto, H. (2016). Perilaku Konsumsi

Pangan Sumber Karbohidrat

Rumahtangga Petani Kelapa Sawit Di

Kecamatan Kandis Kabupaten Siak.

Jurnal Ilmiah Pertanian, 13(1), 22-30.

Heriyanto, H. (2018). Permintaan Pangan

Rumahtangga Provinsi Riau: Model

Linear Approximate Almost Ideal De-

mand System. Jurnal Agribisnis, 20(2), 156-168.

Heriyanto. 2019. "Pola Konsumsi Pangan

Rumah Tangga Petani Kelapa

Sawit Di Kecamatan Minas

Kabupaten Siak Riau.” OSF

Preprints. January 26.

doi:10.31219/osf.io/mh847.

Liu, Haiyan., Wahl, Thomas I., Seale Jr, James

L., Bai, Junfei. 2015. Household com-

position, income, and food-away-from-

home expenditure in urban China,

Food Policy, 51, 97-103

Miller. R dan Poger. E. M. 2000. Teori Mikro ekonomi Intermediate. Rajawali Press, Jakarta.

Obara, Kakuyu., McConnell, Micheal., Dyck, John. 2010. Japan's Beef Market, Journal of Current Issues in Globalization, Vol. 5, Number 4.

Sugiarto. Tedy, H. Brastoro. Rachmat, S. Said, K. 2005. Ekonomi Mikro. Gramedia Pustaka Utama, Jakarta.

Sukirno, S. 2013. Teori Mikro Ekonomi. Edisi Ketiga. Raja Grafindo Persada, Jakarta.

Ugwumba, C.O.A., Effiong, J.A.L. 2013. Analysis oh Household Demand for Beef in Owerri Metropolis of Imo State, Nigeria. Journal of Chemical, Biology and Physical Sciences, 3 (2): 1201-1205

Zulkarnain., Asmawati., Sofyan. 2016. Analisis Konsumsi Daging Sapi Pada Tingkat Rumah Tangga di Provinsi Aceh. Jurnal Agrisep. ISSN: 1411-3848; EISSN: 2579-6372 